\title{
Measurement of volume of macaw palm fruit using traditional and the digital Moiré techniques
}

\author{
Anderson G. Costa ${ }^{1}$, Elisângela Ribeiro ${ }^{2}$, Roberto A. Braga ${ }^{3}$ \& Francisco A. C. Pinto ${ }^{4}$ \\ ${ }^{1}$ Universidade Federal Rural do Rio de Janeiro/Departamento de Engenharia. Rio de Janeiro, RJ. E-mail: acosta@ufrrj.br (Corresponding author) \\ ${ }^{2}$ Universidade Federal de Lavras/Departamento de Ciência da Computação. Lavras, MG. E-mail: elismar1952@hotmail.com \\ ${ }^{3}$ Universidade Federal de Lavras/Departamento de Engenharia. Lavras, MG. E-mail: robbraga@deg.ufla.br \\ ${ }^{4}$ Universidade Federal de Viçosa/Departamento de Engenharia Agrícola. Viçosa, MG. E-mail: facpinto@ufv.br
}

\section{Key words:}

profilometry analysis

optical sensors

maturity stage

Moiré technique

\begin{abstract}
A B S T R A C T
The macaw palm crop has been studied because of its bioenergy potential due to the high oil yield, which is linked to fruit maturity stage. Digital images have been adopted as a contactless way to obtain information about fruit surface area and volume, acting as a sensor for quality control and the classification of fruits, based on physical aspects during the maturation stage. The aim of this study was to estimate the volume of macaw palm fruits from digital models obtained by the Moiré technique using only one camera, associated with digital imageprocessing tools to unwarp the images, allowing the comparison with conventional methods. The volumes obtained by the Moiré technique were compared with those obtained by water displacement method (WDM) and millet-seed displacement method (SDM). The results show that the volumes measured by the Moiré technique exhibited a mean error of $13.54 \%$ compared with the SDM, and $11.09 \%$ when compared to WDM, which indicates that the digital Moiré technique is a robust, low-cost tool to measure the volume of macaw palm fruits.
\end{abstract}

\section{Palavras-chave:}

análise perfilométrica sensores ópticos estádio de maturação técnica de Moiré

\section{Mensuração do volume do fruto de macaúba por meio das técnicas convencionais e pela técnica digital de Moiré}

\section{R E S U M O}

A cultura da macaúba vem sendo estudada devido ao seu potencial bioenergético propiciado pela alta produtividade de óleo que, por sua vez, está associado ao estádio de maturação do fruto. Imagens digitais têm sido utilizadas como forma para extrair informações sem contato sobre a área superficial e volume de frutos, com a finalidade de construir sensores que possam atuar no controle de qualidade e classificação a partir de aspectos físicos ligados ao estádio de maturação. O objetivo deste trabalho foi estimar o volume do fruto de macaúba a partir de imagens digitais obtidas pela técnica de Moiré por meio de uma única câmera associada ao uso de técnicas de correção digital da deformação das imagens, comparando os volumes estimados por métodos convencionais. Os volumes obtidos pela técnica de Moiré foram comparados com os volumes obtidos pelo método de deslocamento de coluna de água e pelo método do deslocamento de sementes de painço. Os volumes medidos pela técnica de Moiré apresentam um erro médio de 13,54 e de 11,09\% quando comparados aos métodos convencionais, sendo considerada uma alternativa robusta e de baixo custo para a mensuração do volume de frutos de macaúba. 


\section{INTRODUCTION}

Among many emergent species with great potential for biofuel production, the macaw palm (Acrocomia aculeata) is considered as a promising crop for raw material in biodiesel production. As its main characteristic, the macaw palm has high oil production in its fruits (Pimentel et al., 2011; Viana et al., 2011). The macaw palm is found in abundance in the Brazilian Cerrado, concentrating mainly in Minas Gerais, Goiás, Mato Grosso do Sul, Mato Grosso, Piauí, Tocantins and Ceará (Lorenzi et al., 2011).

The determination of biometric characteristics of macaw palm fruits, such as weight, volume, diameter, surface area and thickness, is important in the process of evaluation and selection of fruits (Manfio et al., 2011; Bottega et al., 2013); in addition, these characteristics are relevant in the marketing. Optical metrology techniques have been proposed as alternatives for the direct-contact methods with samples analysed to obtain information on fruit surface area and volume (Riddle, 1979; Rashidi \& Ghomali, 2008; Khojastehnazhand et al., 2009; Rashidi et al., 2009).

Digital techniques for measuring boundary surface known as profilometry have been largely employed in agricultural, medical, civil engineering and robotic areas (Braga et al., 2009). Profilometry, for being a powerful tool in the determination of forms and surfaces, allows the classification and evaluation of materials with distinct forms and behaviors (Srinivasan et al., 1985). Among various techniques for the construction of profilometry, the Moiré technique can be considered as a theoretical basis for many methods and digitalization equipment (Sciammarella, 1982; Braga et al., 2009).

The Moiré technique is a method used for measuring deformations, topographic outlines, slopes, curvatures and general forms of objects (Sciammarella, 1982). Its advantage, compared with other sophisticated optical profilometric techniques, such as the laser scanner, consists in obtaining satisfactorily efficiency of the results, without the adoption of costly apparatus. In the agricultural-livestock sector, the Moiré technique is applied in the control of fruit quality, inspection and classification of the topography of general objects and deformations in active pieces (Braga et al., 2009; Albiero et al., 2012). The improvement in image digitalization from the Moiré technique can be achieved by using techniques such as phase shifting, associated with the demodulation of the phase or unwrapping (Judge \& Bryantson-Cross, 1994). However, since the presence of perspective is the basis for performing the Moiré technique, the final result of the digitalized object may have deformations. Correcting deformations can be achieved through the increase in the quality of the images obtained with the cameras or through the digital correction of the deformation. Gomes et al. (2009) proposed a correction of the deformation in the axis out of the plane, thus correcting the distortion in only one axis through a constant value. This calibration by a constant value in only one axis does not correct distortions completely, thus requiring the adoption of other digital techniques to correct deformations in the three axes of the image.

The technique of correction of image distortions, known as unwarping, has been applied to improve images from magnetic resonance (Gholipour et al., 2011) in applications such as images of behavior of broilers (Sevegnani et al., 2005). The potential of application of unwarping in agriculture is great, since the inference on information related to crops can be performed through optical biometry. Studies on the measurement of leaf area are typical examples of this potential (Marcon et al., 2011; Silva et al., 2011; Ribeiro et al., 2013).

The topographic profiles generated by the Moiré technique can be directly related to physical and mechanical attributes of fruits (Rohlfing et al., 2005; Lino et al., 2008), and can be used as an alternative method for the evaluation of biometric characteristics, such as surface area and volume of fruits, potentially for macaw palm. The maturation stage of macaw palm fruits is directly related to the amount of oil obtained from the fruit, which in turn is associated with physical aspects, such as weight and volume (Mota et al., 2011). The closer it is to the harvest point, the higher will be the oil contents in the fruits (Tan et al., 2010).

Since macaw palm biometry is directly associated with maturation degree and oil content of the fruits, this study aimed to estimate the volume of macaw palm fruit from digital images obtained using the Moiré technique, through a robust approach with the use of only one camera associated with digital correction techniques for the images, comparing the volumes estimated through the Moiré technique with volumes estimated through the conventional methods of water displacement and millet-seed displacement.

\section{Material And Methods}

The volumes of macaw palm fruits were digitally estimated using the Moiré Technique (MT) and the conventional methods of water displacement (WDM) and millet-seed displacement (SDM).

MT images were obtained using a projector $\left(\right.$ Epson $^{\circledR}$ Model S8) with intensity of 2500 lumens, a portable computer $\left(\right.$ Acer $^{\circledR}$ - Model ASPIRE 5252-V874) and a digital camera $\left(\right.$ Canon $^{\circledR}$ - Model EO Digital Rebel XTI) with resolution of 10 megapixels (Figure 1A). The projection grids above the analysed object had a thickness of $3 \mathrm{~mm}$ and step of $7 \mathrm{~mm}$. Images were collected with the grids projected on the object (Figure 1B) and on the screen, without the object. Figure 1C shows an image resulting from the initial pre-processing that eliminates the image background through a logic operation, using an image with the fruit without the grids in the binary form, in order to create the edges to remove the background. The estimate of fruit volume was calculated through a computational routine (Figure 2).

The deformation in the images caused by the use of only one camera was corrected using a mathematical model based on an actual sphere as an image of the reference surface, according to Eq. 1.

$$
(x-a)^{2}+(y-b)^{2}+(z-c)^{2}=r^{2}
$$

Where $\mathrm{a}, \mathrm{b}$ and $\mathrm{c}$ are coordinates of the center of the sphere allocated in the axes $\mathrm{x}, \mathrm{y}$ and $\mathrm{z}$. The term ' $\mathrm{r}$ ' represents the radius of the known sphere. 

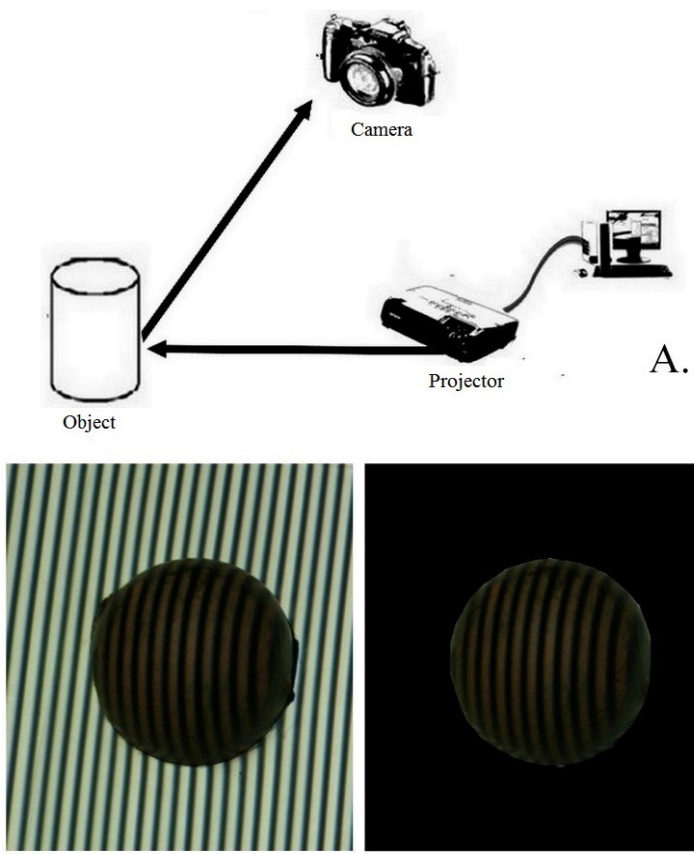

B.

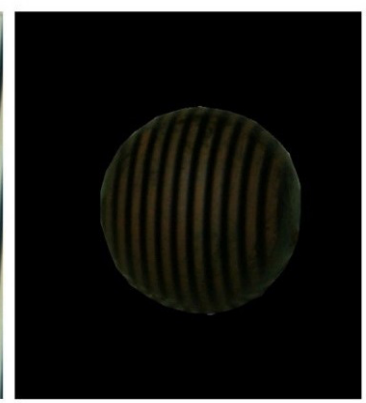

C.

Figure 1. Experimental configuration and images generated by the Moiré Technique $(A)$ before $(B)$ and after $(C)$ preprocessing

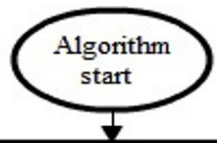

Reading of the images of the grid without the object

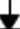

Reading of the images of the object without the projected grids

Subtraction of images of the object with projected grids and images of the grid without the object

Utilization of a Gaussian filter to remove noises

Generation of one of the faces of the object; the union of the faces of the object

v

Estimation of fruit volume from the equation of the sphere volume

$\mathrm{VI}$

Figure 2. Flowchart of the computational routine for calculating the volume of a sphere

After identifying the image of the reference surface, the digitalized image was corrected using a polynomial function (Eq. 2 ). The degree of the polynomial corresponds to the value of the highest exponent of the variable, i.e., the ' $n$ ' value of the function.

$$
\mathrm{P}(\mathrm{x})=\sum_{\mathrm{i}=0}^{\mathrm{n}} \mathrm{a}_{\mathrm{i}} \mathrm{x}^{\mathrm{i}}
$$

Each line of the actual and the digitalized images was adjusted by a single polynomial that showed the best fit, thus performing the correction of the complete image.
For the determination of the volumes through WDM, each fruit was placed in a graduated cylinder $(200 \mathrm{~mL})$ containing a known volume of water (initial volume). Based on the difference between the final volume (after immersion of the fruit) and the initial volume, fruit volume was obtained (Manfio et al., 2011). The measurements through SDM were obtained from the volume of millet seeds displaced after immerging the fruit in a graduated cylinder (mL) (Griswold, 1972).

Twenty nine macaw palm fruits in similar maturation stages were used, and the volume of each fruit was estimated through the three methods described. Fruit volume estimated by MT was compared with the respective volumes measured by WDM and SDM, based on the percent error between the measuring methods. In addition, WDM x MT and SDM x MT were compared using the difference between means (Dm) and standard error (Er), and Pearson's correlation coefficient at 0.05 probability level.

The difference between the means of volumes measured through each method was analysed using Student's t-test at 0.01 probability level, in order to verify the statistical difference between the evaluated methods.

In addition, the weight of each fruit was used as a reference parameter for the verification of the precision of each method. The relationship between the volumes estimated through each method and the weight of each fruit were evaluated using simple regression analysis, at 0.05 probability level.

\section{RESUlts AND Discussion}

The application of the unwarping technique to correct the deformation of fruit images, showed a sixth-order polynomial equation as a result, observed in Eq. 3.

$$
\begin{aligned}
\mathrm{P}(\mathrm{x}) & =-32.3425 \mathrm{x}^{6}+117.0517 \mathrm{x}^{5}- \\
& -167.4241 \mathrm{x}^{4}+120.7227 \mathrm{x}^{3}- \\
& -46.5141 \mathrm{x}^{2}+9.7397 \mathrm{x}-0.2394
\end{aligned}
$$

Figure 3 shows the 3D result of the correction using the unwarping method for one of the fruits. The threedimensional representation of half the fruit shows a smooth surface, without noise and without problems of discontinuity on the edges, as questioned by Braga et al. (2009), evidencing that the use of only one camera associated with digital correction can overcome the problems caused by the perspective.

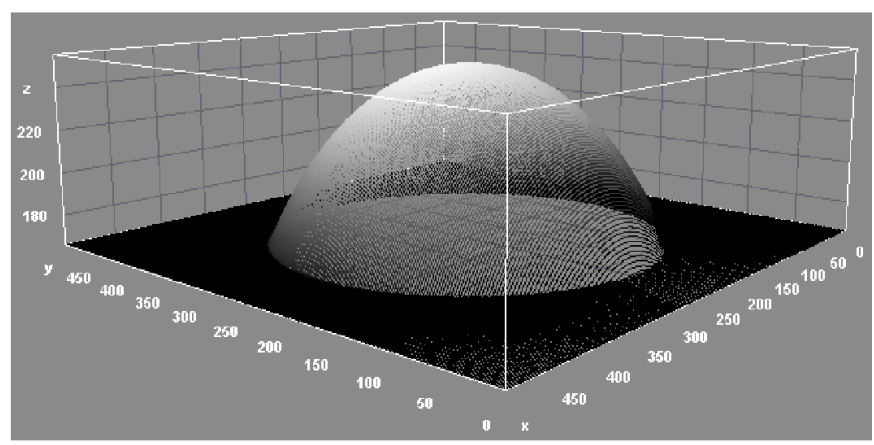

Figure 3. Three-dimensional result using the unwarping method for half the fruit of macaw palm 
The correction or "unwarping" is a necessary step for the improvement of images, according to Gholipour et al. (2011) and Sevegnani et al. (2005). The deformations in the digitalized images of macaw palm fruits generated by the perspective, due to the use of only one camera, were corrected by using the technique of correction of image deformations. This shows that the presented model and the proposed protocol for obtaining the images can be applied in other studies.

Determining biometric characteristics, such as the volume of macaw palm fruits, is important in the process of fruit evaluation and selection (Manfio et al., 2011). Based on the estimate of volume of macaw palm fruits, it is possible to develop systems capable of relating this attribute to oil content and maturation stage of the fruits (Bottega et al., 2013). The main advantage of performing image digitalization through MT for the determination of physical attributes is that it is a non-destructive, robust and precise method (Forbes \& Tattersfield, 1999).

The volumes measured using each method with the respective errors, in the comparison of MT with WDM and SDM, are shown in Table 1. Measuring the volume through MT promoted mean error $13.54 \%$ higher compared with SDM, while the comparison with WDM showed an error of $11.09 \%$. In the comparison of MT $x$ WDM, $64.29 \%$ of the measurements showed errors of $0-10 \%, 32.14 \%$ showed errors of $10-30 \%$ and $3.57 \%$ showed error higher than $30 \%$. The minimum error was $1.21 \%$ and the maximum was $34.36 \%$.

Table 1. Comparison of fruit volumes $\left(\mathrm{cm}^{3}\right)$ obtained by the Moiré Technique (MT) with the methods of water displacement (WDM) and millet-seed displacement (SDM), with the respective percent errors $(\mathrm{Er})$

\begin{tabular}{ccccccc}
\hline Sample & WDM & MT & $\begin{array}{c}\mid \text { Er } \mid \\
(\%)\end{array}$ & SDM & MT & $\begin{array}{c}\mid \text { Er } \mid \\
(\%)\end{array}$ \\
\hline 1 & 41.18 & 39.72 & 3.54 & 41.50 & 39.72 & 4.29 \\
2 & 35.26 & 43.62 & 23.70 & 37.00 & 43.62 & 17.88 \\
\hline 3 & 44.12 & 48.92 & 10.88 & 43.00 & 48.92 & 13.77 \\
4 & 35.29 & 32.09 & 9.07 & 36.00 & 32.09 & 10.86 \\
5 & 41.18 & 47.40 & 15.10 & 36.50 & 47.40 & 29.85 \\
6 & 41.18 & 38.47 & 6.58 & 39.50 & 38.50 & 2.61 \\
\hline 7 & 50.00 & 49.39 & 1.21 & 47.00 & 49.39 & 5.09 \\
8 & 44.11 & 45.20 & 2.47 & 40.50 & 45.20 & 11.60 \\
\hline 9 & 50.00 & 53.99 & 7.99 & 50.00 & 53.99 & 7.99 \\
10 & 41.17 & 42.12 & 2.31 & 40.50 & 42.12 & 4.01 \\
11 & 47.06 & 53.75 & 14.22 & 48.00 & 53.75 & 11.99 \\
12 & 41.18 & 42.04 & 2.08 & 41.50 & 42.04 & 1.297 \\
\hline 13 & 41.18 & 40.64 & 1.32 & 41.00 & 40.64 & 00.89 \\
14 & 38.23 & 47.27 & 23.65 & 37.00 & 47.27 & 27.77 \\
\hline 15 & 38.23 & 43.69 & 14.29 & 38.00 & 43.69 & 14.98 \\
16 & 38.23 & 35.28 & 7.73 & 36.00 & 35.28 & 02.01 \\
\hline 17 & 38.23 & 40.09 & 4.86 & 35.00 & 40.09 & 14.53 \\
18 & 32.35 & 40.28 & 24.53 & 31.50 & 40.28 & 27.89 \\
\hline 19 & 38.23 & 44.06 & 15.24 & 37.00 & 44.06 & 19.07 \\
\hline 20 & 41.18 & 45.23 & 9.85 & 39.00 & 45.23 & 16.00 \\
\hline 21 & 41.18 & 48.14 & 16.90 & 38.00 & 48.14 & 26.69 \\
22 & 38.23 & 37.33 & 2.35 & 37.00 & 37.33 & 0.89 \\
\hline 23 & 38.23 & 48.64 & 27.22 & 35.00 & 48.64 & 38.96 \\
24 & 35.25 & 47.36 & 34.36 & 35.50 & 47.36 & 33.41 \\
\hline 25 & 47.05 & 50.14 & 6.56 & 43.50 & 50.14 & 15.26 \\
\hline 26 & 50.00 & 53.22 & 6.44 & 51.00 & 53.22 & 4.356 \\
\hline 27 & 50.00 & 46.29 & 7.41 & 47.50 & 46.29 & 2.54 \\
\hline 28 & 38.23 & 41.55 & 8.68 & 35.00 & 41.55 & 18.71 \\
\hline 29 & - & - & - & 39.00 & 41.91 & 07.46 \\
Mean & 41.28 & 44.50 & 11.09 & 39.90 & 44.41 & 13.54 \\
\hline & & & & & & \\
\hline
\end{tabular}

The comparison MT x SDM showed that $41.38 \%$ of the measurements had errors of $0-10 \%, 51.72 \%$ showed errors of $10-30 \%$ and $6.90 \%$ showed errors higher than $30 \%$. The minimum value was $0.89 \%$ and the maximum was $38.96 \%$.

The highest errors between estimates of volume obtained by conventional and digital methods, as observed in the samples 23 and 24, can be associated with irregularities in fruit shape. From the perspective of volume estimation using digital images, the closer to the shape of a sphere, the fewer deformations and noises in the digitalization of fruit surfaces tend to occur, which guarantees higher precision of measurements. On the other hand, the application of conventional methods in fruits with irregular forms can hamper the correct volume measurement, because the verification is performed through visual observation of the graduated cylinder.

In the comparison of WDM x MT and SDM x MT (Table 2 ), there were significant correlations of 0.654 and 0.622 , respectively. The mean difference $(\mathrm{Dm})$ and the standard error were $3.75 \mathrm{~cm}^{3}$ and 3.78 for WDM x MT and $4.51 \mathrm{~cm}^{3}$ and 3.92 for SDM x MT, respectively. These results suggest that volumes measured through MT are close to the values of conventional methods, especially WDM, and reinforce the hypothesis that the application of MT with only one camera associated with correction of image deformations, unwarping and unwrapping, can be performed as a method for the analysis of the volume of macaw palm fruits.

The analysis of the differences between the means, in the comparison of the methods for fruit volume measurement (Table 3), showed that the volumes estimated by MT were not considered as equal to those estimated by conventional methods, which suggested the hypothesis that the digitally measured volumes can be more precise. In the comparison between the conventional methods, WDM and SDM, they were statistically equal. Although the conventional methods, WDM and SDM, are extensively used for the measurement of volume, some errors can occur during their use, especially related to the reading of the displaced water column.

Since macaw palm fruits were in an approximate maturation stage and, therefore, considered with approximate densities, the weight of the fruits was used as a reference parameter for the analysis of precision of the volume measurements.

Table 2. Statistical comparison of the Moiré Technique (MT) with the methods of water displacement (WDM) and millet-seed displacement (SDM)

\begin{tabular}{ccccc}
\hline Comparison between methods & $\mathbf{N}$ & Dm & Er & $\mathbf{r}$ \\
WDM x MT & 28 & 3.75 & 3.78 & $0.65^{\star}$ \\
SDM x MT & 29 & 4.51 & 3.92 & $0.62^{\star}$ \\
\hline
\end{tabular}

$\mathrm{N}$ - Number of samples; Dm - Mean difference $\left(\mathrm{cm}^{3}\right)$; $\mathrm{Er}$ - Standard error; $\mathrm{r}$ - Correlation; ${ }^{*}$ ) Significant correlation at 0.05 probability level

Table 3. Analysis of the difference between mean volumes of macaw palm fruits obtained using the methods of water displacement (WDM) and millet-seed displacement (SDM) and the Moiré technique (MT), according to Student's t-test

\begin{tabular}{ccc}
\hline & Difference between means $\left(\mathbf{c m}^{3}\right)$ & p-value \\
MT x WDM & $3.75^{*}$ & 0.0005 \\
MT x SDM & $4.512^{*}$ & $0.9 \times 10^{-5}$ \\
WDM $\times$ SDM & 0.764 & 0.2603 \\
\hline${ }^{*}$ Difference between means at 0.01 probability level
\end{tabular}


In the analysis of the relationship between the volumes measured using the three methods and fruit weight, the volumes obtained through conventional methods, WDM and SDM, did not show significant correlation with fruit weight $\left(\mathrm{R}^{2}\right.$ $=0.306$ and 0.305 ); on the other hand, the volumes measured by the digital method (MT) showed a significant correlation, with $R^{2}=0.837$ (Figure 4). This fact suggests that, when the relationship between volume and weight is considered as a comparison parameter, the volumes estimated by MT tend to be more precise than those obtained through conventional methods.

Previous studies, such as Negreiros et al. (2007), who evaluated the relationship between physical characteristics and pulp yield of passion fruits, and Oliveira et al. (2013), who physically characterized babassu fruits in order to obtain attributes that helped oil extraction, also have shown direct correlation between these parameters. Although conventional, the methods of WDM and SDM may fail at dimensioning the actual volume, since they depend on manipulation and the reading of water column height, which make them subjective and susceptible to distortions.

Negreiros et al. (2007) also report that passion fruits with greater diameters allowed obtaining heavier fruits with higher pulp yield. In macaw palm, the oil content found in the pulp can reach up to $70 \%$ in dry basis (Mota et al., 2011). Thus, fruits with larger volumes tend to show higher pulp yield, generating greater amount of mass to be processed for oil extraction.

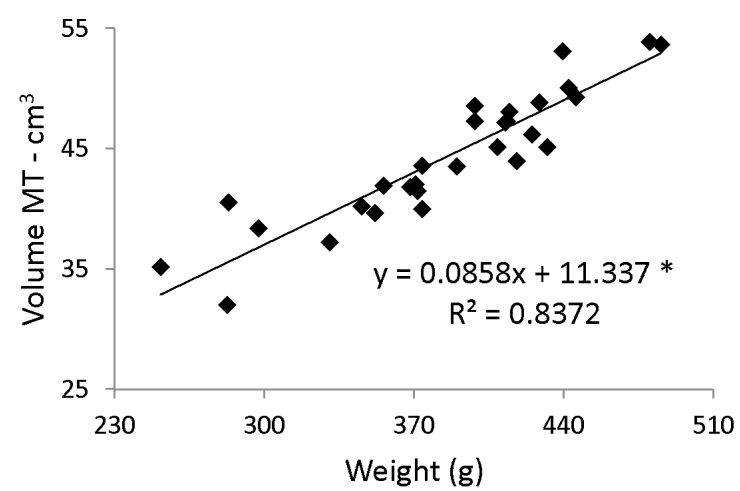

Figure 4. Relationship between the volume of macaw palm fruits measured through the Moiré Technique (MT) and the weight

\section{Conclusions}

1. The measurement of volume through the Moiré technique promoted a mean error of $13.54 \%$ compared with the milletseed displacement method, while the comparison with the water displacement method showed an error of $11.09 \%$, which allowed concluding that the Moiré technique can be used as a digital analysis method and is a low-cost, robust alternative for the measurement of volume of macaw palm fruits.

2. The application of techniques to correct image distortions allowed obtaining a digital profile without noises or discontinuities on the edges, showing that using only one camera associated with digital correction can overcome the problems caused by perspective.

3. Based on the analysis of the relationship between the measured volumes and fruit weights, the Moiré technique showed a significant correlation $\left(\mathrm{R}^{2}=0.837\right)$, indicating that the volumes estimated by MT tend to be more precise than those estimated by conventional methods.

\section{ACKNOWLedgments}

To the Federal University of Viçosa, to the Federal University of Lavras and to CNPq (National Council for Scientific and Technological Development), CAPES (Coordination for the Improvement of Higher Education Personnel), FAPEMIG (Minas Gerais Research Foundation) and FINEP (Funding Authority for Studies and Projects), which partially funded this research.

\section{Literature Cited}

Albiero, D.; Araújo, M. C.; Ferraz, A. C. O.; Fabbro, I. M. dal; Maciel, A. J. S. Moiré optical technique for evaluation of cashew nuts (Anacardium Occidentale, L.) ISOSTRAIN. Varia Scientia Agrarias, v.9, p.9-20, 2012.

Bottega, E. L.; Medeiros, W. N.; Matsimbe, S.; Pinto, F. A. C.; Queiroz, D. M. Estimativa do volume de mesocarpo de frutos da Macaúba utilizando processamento de imagens digitais. Campo Digital, v.8, p.28-36, 2013.

Braga, R. A.; Oliveira, B. S.; Costa, R. M., Lino, A. C. L.; Fabbro, I. M. dal. Suppression of border effects in Moiré techniques using threedimensional methods. Biosystems Engineering, v.102, p.18, 2009. http://dx.doi.org/10.1016/j.biosystemseng.2008.09.031

Forbes, K. A.; Tattersfield, G. M. Estimating fruit volume from digital images. In: IEEE Africon, 5, Proceedings...Africon: Africon Conference in Africa, p.107-112, 1999. http://dx.doi.org/10.1109/ afrcon.1999.820775

Gholipour, A.; Kehtarnavaz, N.; Scherrer, B.; Warfield, S. K. On the accuracy of unwarping techniques for the correction of susceptibility-induced geometric distortion in magnetic resonance Echo-planar images. In: Enginnering in Medicine and Biology Society, EMBC, 2011 Proceedings...Annual International Conference of IEEE, Milian: IEEE, 2011. p.6997-7000. http:// dx.doi.org/10.1109/iembs.2011.6091769

Gomes, T. S.; Braga, R. A.; Lino, A. C. L.; Rabelo, G. F.; Costa, R. M. Calibração da técnica de Moiré aplicada a perfilometria de protótipos mecânicos. Ciência e Agrotecnologia, v.33, p.574-579, 2009. http://dx.doi.org/10.1590/S1413-70542009000200033

Griswold, R. M. Estudo experimental dos alimentos. São Paulo: EDUSP, 1972. 146p.

Judge, T. R; Bryanston-Cross P. J. A review of phase unwrapping techniques in fringe analysis. Optics and Lasers in Engineering. Elsevier. v.21, p.199-239, 1994.

Khojastehnazhand, M.; Omid, M.; Tabataeefar, A. Determination of orange volume and surface area using image processing technique, International Agrophysics, v.23, p.237-242, 2009.

Lino, C. L.; Fabbro, I. M. dal; Almeida, C. Fruit surface topographic survey supported by a phase shifting projection Moiré technique. In: "RIAO/OPTILAS 2007: Ibero-American Conference on Optics (RIAO), 6; Latim-American Meeting on Optics, 9, Campinas. Anais...Campinas: Lasers and Applicattion, AIP Publishing, 2008. 1028p. 
Lorenzi, G. M. A. C.; Pimentel, L. D.; Paula, S. R.; Negrelle, R. R. B.; Paes, J. M. V. Prospecção da cadeia produtiva dos frutos da palmeira macaúba no estado de Minas Gerais. Informe Agropecuário, v.32, p.41-51, 2011.

Manfio, C. E.; Montoike, S. Y.; Santos, C. E. M.; Pimentel, L. D.; Queiroz, V.; Sato, A. Repetibilidade em características biométricas dos frutos de Macaúba, Ciência Rural, v.41, p.70-76, 2011. http:// dx.doi.org/10.1590/S0103-84782011000100012

Marcon, M.; Ribeiro, K. M.; Braga, R. A.; Paglis, C. M.; Scalco, M. S.; Horgan, G. W. Estimation of total leaf area in perennial plants using image analysis. Revista Brasileira de Engenharia Agrícola e Ambiental, v.15, p.96-101, 2011. http://dx.doi.org/10.1590/ S1415-43662011000100014

Mota, C. S.; Corrêa, T. R.; Grossi, J.A.S.; Castricini, A.; Ribeiro, A. S. Exploração sustentável da macaúba para produção de biodiesel: colheita, pós-colheita e qualidade dos frutos. Informe Agropecuário, v.32, p.41-51, 2011.

Negreiros, J. R. S.; Álvares, V. S.; Bruckner, C. H.; Morgado, M. A. D.; Cruz, C. D. Relação entre características físicas e o rendimento de polpa de maracujá-amarelo. Revista Brasileira de Fruticultura, v.29, p.546-549, 2007. http://dx.doi.org/10.1590/ S0100-29452007000300026

Oliveira, A. I. T.; Alexandre, G. P.; Mahmoud, T. S. Babaçu (Orbignya $s p)$ : Caracterização física de frutos e utilização de solventes orgânicos para extração de óleo. Biochemistry and Biotechnology Reports, v.2, p.126-129, 2013. http://dx.doi.org/10.5433/23165200.2013v2n3espp 126

Pimentel, L. D.; Bruncker, C. H.; Martinez, H. E. P.; Teixeira, C. M.; Motoike, S. Y.; Pedroso Neto, J. C. Recomendação de adubação e calagem para o cultivo de macaúba: $1^{\circ}$ aproximação. Informe Agropecuário, v.32, p.20-30, 2011.

Rashidi, M.; Gholami, M. Determination of kiwifruit volume using ellipsoid approximation and image-processing methods. International Journal of Agriculture \& Biology, v.10, p.375-380, 2008.
Rashidi, M.; Gholami, M.; Abbassi, S. Cantaloupe volume determination through image processing, Journal of Agricultural Science and Technology, v.11, p.623-631, 2009.

Ribeiro, K. M.; Braga, R. A.; Scalco, M. S.; Horgan, G. W. Leaf area estimation of médium size plants using optical metrology. Revista Brasileira de Engenharia Agrícola e Ambiental, v.17, p.595-601, 2013. http://dx.doi.org/10.1590/S1415-43662013000600004

Riddle, D. F. Calculus and analytic geometry. Belmont: Wadsworth Publishing Company, 1979. p.505-507.

Rohlfing, T; Schaupp, F; Haddad, D; Brandt, R.; Haase, A; Menzel, R; Calvin R. Maurer, C. R. M. J. "Unwarping confocal microscopy images of bee brains by nonrigid registration to a magnetic resonance microscopy image", Journal of Biomedical Optics, v.10, p.024018-0240188, 2005. http://dx.doi.org/10.1117/1.1896025

Sciammarella, C. A. The Moiré method-A review. Experimental Mechanics, v.44, p.418-433, 1982. http://dx.doi.org/10.1007/ BF02326823

Sevegnani, K. B.; Caro, I. W.; Pandorfi, H.; Silva, I. J. O.; Moura, D. J. Zootecnia de precisão: Análise de imagens no estudo do comportamento de frangos de corte em estresse térmico. Revista Brasileira de Engenharia Agrícola e Ambiental, v.9, p.115-119, 2005. http://dx.doi.org/10.1590/S1415-43662005000100017

Silva, G. C. A.; Yanagi Júnior, T.; Silva, E.; Braga Júnior, R. A.; Campos, A. T. Eggs' topography recovery by means of the Moiré technique and by an independent calibration. Engenharia Agrícola, v.31, p.211-218, 2011.

Srinivasan, V.; Liu, H. C.; Halioua, M. Automated phase measuring profilometry: A phase mapping approach. Applied Optics, v.24, p.185-188, 1985. http://dx.doi.org/10.1364/AO.24.000185

Tan, Y. A.; Low, K. W.; Lee, C. K.; Low, K. S. Imaging technique for quantification of oil palm fruit ripeness and oil content. European Journal of Lipid Science and Technology. v.112, p.838-843, 2010. http://dx.doi.org/10.1002/ejlt.201000020

Viana, M. C. M.; Silva, E. A.; Queiroz, D. S.; Paes, J. M. V.; Albernaz, W. M.; Fraga, G. Cultivo de macaúba em sistemas agrossilvipastoris. Informe Agropecuário, v.32, p.70-80, 2011. 